\title{
Microinjection of Actin-Binding Proteins and Actin Antibodies Demonstrates Involvement of Nuclear Actin in Transcription of Lampbrush Chromosomes
}

\author{
Ulrich Scheer, ${ }^{*}$ Horst Hinssen, ${ }^{\dagger}$ \\ Werner W. Franke," and Brigitte M. Jockusch ${ }^{\ddagger}$ \\ *Division of Membrane Biology and Biochemistry \\ Institute of Cell and Tumor Biology \\ German Cancer Research Center \\ D-6900 Heidelberg, Federal Republic of Germany \\ 'Institute of Molecular Biology \\ Austrian Academy of Sciences \\ A-5020 Salzburg, Austria \\ ₹Developmental Biology Unit \\ University of Bielefeld \\ D-4800 Bielefeld, Federal Republic of Germany
}

\section{Summary}

Nuclei of amphibian oocytes contain large amounts of actin, mostly in unpolymerized or short-polymer form. When antibodies to actin or actin-binding proteins (fragmin and the actin modulator from mammalian smooth muscle) are injected into nuclei of living oocytes of Pleurodeles waltlii, transcription of the lampbrush chromosomes, but not of the rRNA genes, is inhibited. When transcription is repressed by drugs or RNA is digested by microinjection of RNAase into oocyte nuclei, an extensive meshwork of actin filament bundles is seen in association with the isolated lampbrush chromosomes. These observations indicate a close relationship between the state of nuclear actin and transcriptional activity and suggest that nuclear actin may be involved in transcriptional events concerning protein-coding genes.

\section{Introduction}

Considerable evidence has accumulated over the past decade showing that actin is a major protein of interphase nuclei in a wide variety of eucaryotic cells. Actin has been identified in chromatin and nuclear fractions isolated from organisms as diverse as slime molds (Jockusch et al., 1974; LeStourgeon et al., 1975; Pederson, 1977) and mammals (Ohnishi et al., 1964; Douvas et al., 1975; Paulin et al., 1976; Peterson and McConkey, 1976; for review see LeStourgeon, 1978). However, such studies do not prove unequivocally that the actin is localized in the nuclei since cytoplasmic contamination could not be rigorously excluded (for detailed discussion of this problem see Comings and Harris, 1976; LeStourgeon, 1978). More convincing are the demonstrations that manually isolated and cleaned nuclei of ameba and amphibian oocytes contain relatively large amounts of actin (Clark and Merriam, 1977; Goldstein et al., 1977a, 1977b; DeRobertis et al., 1978; Clark and Rosenbaum, 1979; Krohne and Franke, 1980a, 1980b; Gounon and Karsenti, 1981), reaching total nuclear concentrations of $3-4 \mathrm{mg} / \mathrm{ml}$ in amphibian oocytes (Clark and Rosenbaum, 1979; Krohne and Franke, 1980a; Gounon and Karsenti, 1981). In amphibian oocytes, the nuclear actin has been identified as both $\beta$ and $\gamma$-actin
(Vandekerckhove et al., 1981) but, in contrast to cytoplasmic actin, most of this nuclear actin has been recovered in a soluble, unpolymerized form (Clark and Merriam, 1977; Clark and Rosenbaum, 1979; Gounon and Karsenti, 1981). In addition, nuclear localization of actin has been unequivocally demonstrated for the filament bundles of actin polymers induced by treatment of cells with dimethyl sulfoxide (Fukui, 1978; Sanger et al., 1980; Wehland et al., 1980).

In spite of the widespread occurrence of nuclear actin and its high intranuclear concentration, its function is unknown. Some authors have discussed the possibility that actin might be involved in modifications of the structural state of chromatin such as heterochromatin formation in interphase nuclei and chromosome condensation during mitosis and meiosis (LeStourgeon et al., 1975; Paulin et al., 1976; Goldstein et al., 1977b; Karsenti et al., 1978; Rubin et al., 1978; Rungger et al., 1979), in the positioning and translocation of ribonucleoproteins (Gounon and Karsenti, 1981; Reddy and Busch, 1983), and in intranuclear mitotic divisions (Jockusch et al., 1974). On the other hand, it has been argued that the presence of actin in interphase nuclei is of no functional significance at all but rather is explained by "the trivial reason that the nuclear envelope is no barrier to free movement of that protein between the two compartments" (Goldstein et al., 1977a).

If the presence of actin in nuclei is of functional significance, experimentally induced alterations of the state of actin should interfere with these functions. We have recently shown that microinjection of antibodies into nuclei of living amphibian oocytes is a useful approach for the analysis of the functional role of the specific nuclear antigen. For instance, injection of antibodies to RNA polymerase II, histone $\mathrm{H} 2 \mathrm{~B}$, or the nonhistone protein $\mathrm{HMG}-1$ into the oocyte nucleus efficiently inhibits transcription of the loops of the lampbrush chromosomes, indicating that these proteins are involved in the transcription of proteincoding genes (Scheer et al., 1979a; Bona et al., 1981; Kleinschmidt et al., 1983). A similar interference with transcription by microinjected antibodies to histones, HMG proteins, and RNA polymerase I has been reported for cultured somatic cells (Einck and Bustin, 1983; Schlegel et al., submitted).

In the present study we have microinjected actin antibodies and actin-binding proteins with specific effects on the polymer state of actin, i.e. fragmin from Physarum polycephalum (Hasegawa et al., 1980; Hinssen, 1981a, 1981b) and actin modulator protein from pig stomach smooth muscle (Hinssen et al., 1984) into the nuclei of living oocytes of the salamander Pleurodeles waltlii. Surprisingly, these substances blocked transcription of the lampbrush chromosome loops, suggesting a functional role for nuclear actin in gene expression.

\section{Results}

Amphibian oocytes are known for the exceptionally high transcriptional activity of all three of their RNA polymerase classes (for review see Sommerville, 1977). In particular, 
vitellogenic stages are characterized by maximal transcription of nucleolar genes and of the protein-coding genes located in the lateral loops of lampbrush chromosomes. Transcription units of both kinds of genes can be readily visualized by electron microscopy of spread preparations (Miller and Beatty, 1969; Miller and Bakken, 1972; Miller, 1981; Scheer et al., 1979b; Scheer and Zentgraf, 1982). In addition, transcribed lampbrush chromosome loops are easily recognized in the light microscope (e.g., Callan and Lloyd, 1960; Callan, 1982; LaCroix, 1968) and their presence is directly related to the transcriptional process. As has been shown by several authors, inhibition of RNA polymerase II-mediated transcription by drugs and microinjected antibodies to chromosomal proteins results in rapid loop retraction (Izawa et al., 1963; Snow and Callan, 1969; Mancino et al., 1971; Scheer et al., 1979a; Bona et al., 1981; Kleinschmidt et al., 1983). It is important to note that these phenomena have been observed only in living oocytes and have not been noted when isolated nuclei were treated with such drugs (e.g. Snow and Callan, 1969; Morgan et al., 1980; Schultz et al., 1981).

In the present study we have used nuclei from growing oocytes of Pleurodeles waltlii manually isolated in Trisbuffered saline $\left(75 \mathrm{mM} \mathrm{KCl}, 25 \mathrm{mM} \mathrm{NaCl}, 0.1 \mathrm{mM} \mathrm{CaCl}_{2}\right.$, $10 \mathrm{mM}$ Tris- $\mathrm{HCl}, \mathrm{pH}$ 7.2). Upon mechanical removal of the nuclear envelope, the nucleoplasm disperses rapidly, and within a few minutes the lampbrush chromosomes spread out on the bottom of the observation chamber and are visible by phase contrast microscopy (Figures 1a, 2a).

\section{Microinjection of Actin Antibodies}

The affinity-purified rabbit antibodies ( $\operatorname{gG}$ ) used for the injection studies were raised against smooth muscle actin from chicken gizzard (Jockusch et al., 1978). They crossreacted with actin of Pleurodeles oocytes as demonstrated by immunofluorescence microscopy. Cryostat sections of Pleurodeles ovaries revealed a strongly fluorescing cortical layer in the cytoplasm of the oocytes, a region known to be rich in bundles of F-actin microfilaments (Franke et al., 1976; Gall et al., 1983). Significant nuclear fluorescence has not been observed in such experiments, in spite of the high actin concentrations present, probably because of its largely nonfilamentous and soluble state (for special technical problems in immunolocalization of soluble nucleoplasmic proteins in oocytes, see Krohne and Franke, 1980a). In biochemical experiments we have also determined the amount of actin present in manually isolated nuclei of Pleurodeles oocytes of the size class used for the injection experiments. From densitometry of polypeptides separated by SDS-polyacrylamide gel electrophoresis a total amount of $0.12 \mu \mathrm{g}$ actin per nucleus was determined, corresponding to an intranuclear concentration of approximately $2.4 \mathrm{mg} / \mathrm{ml}$ (a similar figure has been reported by Gounon and Karsenti, 1981). As previously shown in Xenopus laevis (Dabauvalle and Franke, 1982), two-dimensional gel electrophoresis revealed $\beta$ - and $\gamma$ actin exclusively (not shown).

Approximately $4 \mathrm{hr}$ after injection of moderate amounts
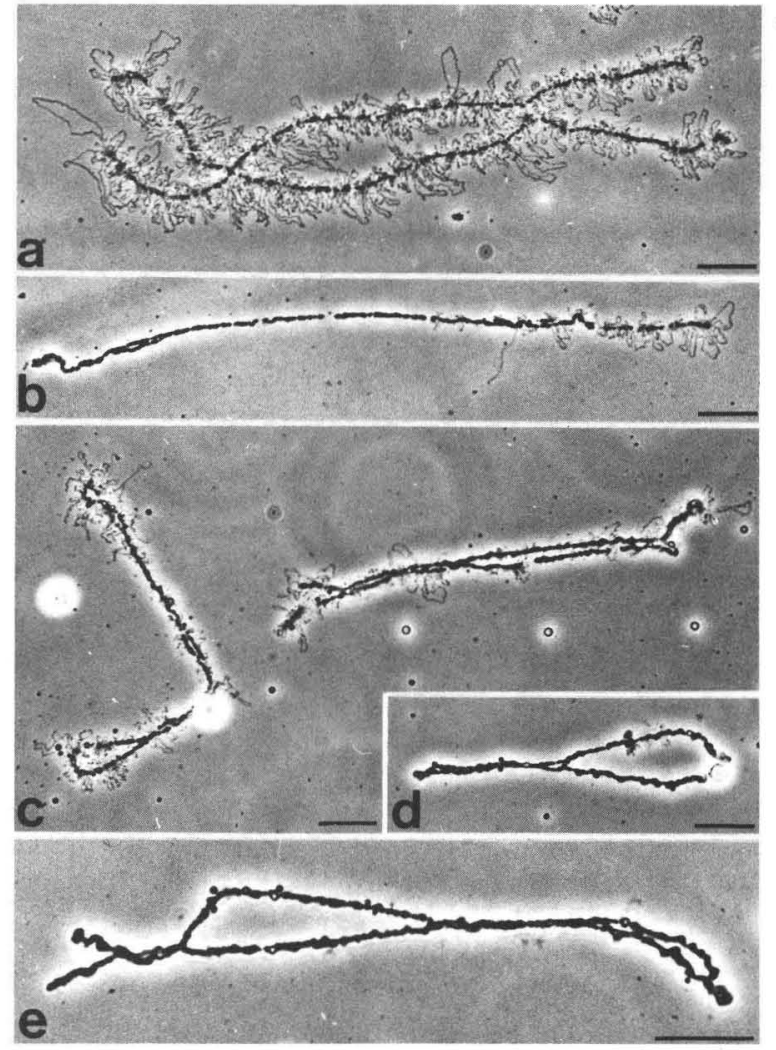

Figure 1. Progressive Retraction of the Lampbrush Chromosome Loops after Injection of Antibodies to Actin into Nuclei of Living Oocytes of Pleurodeles waltlii as Seen by Phase Contrast Microscopy

(a) Chromosomes isolated $1 \mathrm{hr}$ after injection of affinity-purified anti-actin lgG (0.2 mg/ml, $5 \mathrm{nl}$ per nucleus) still appear normal.

(b-d) The majority of the lateral loops are retracted when chromosomes are isolated $4.5 \mathrm{hr}$ after injection of actin antibodies. The distribution of the remaining loops is heterogeneous-i.e., they are either clustered at certain sites of the chromosomal axis next to completely condensed regions (b) or are confined to some chromosome bivalents (c), whereas others are almost completely condensed (d). Upon injection of $10 \mathrm{nl}$ anti-actin solution per nucleus the vast majority of the loops is retracted after $4.5 \mathrm{hr}$ (a representative chromosome bivalent is shown in e). Bars: $20 \mu \mathrm{m}$.

of actin antibodies ( $5 \mathrm{nl} ; 0.2 \mathrm{mg} \mathrm{lgG} / \mathrm{ml}$ ) into nuclei of living Pleurodeles oocytes, pronounced alterations in chromosomal morphology were noted (Figures $1 \mathrm{~b}-1 \mathrm{~d}$ ). Most of the lateral loops of the lampbrush chromosomes were retracted and integrated into the chromomeres. A certain, variable proportion of the loops, however, seemed to be more resistant to the effects induced by the antibodies. In a representative experiment three categories of chromosomes could be distinguished: chromosomes with almost all loops collapsed (Figure 1d); chromosomes covered along their entire lengths with loops generally smaller than those of control preparations (Figure 1c); and chromosomes with both loop-containing and loop-deficient regions (Figure 1b). After prolonged intervals between antibody injection and chromosome preparation (up to $8 \mathrm{hr}$ ) the proportion of completely condensed chromosomes was usually increased but some chromosomes containing small regions with loop projections could still be recognized. 

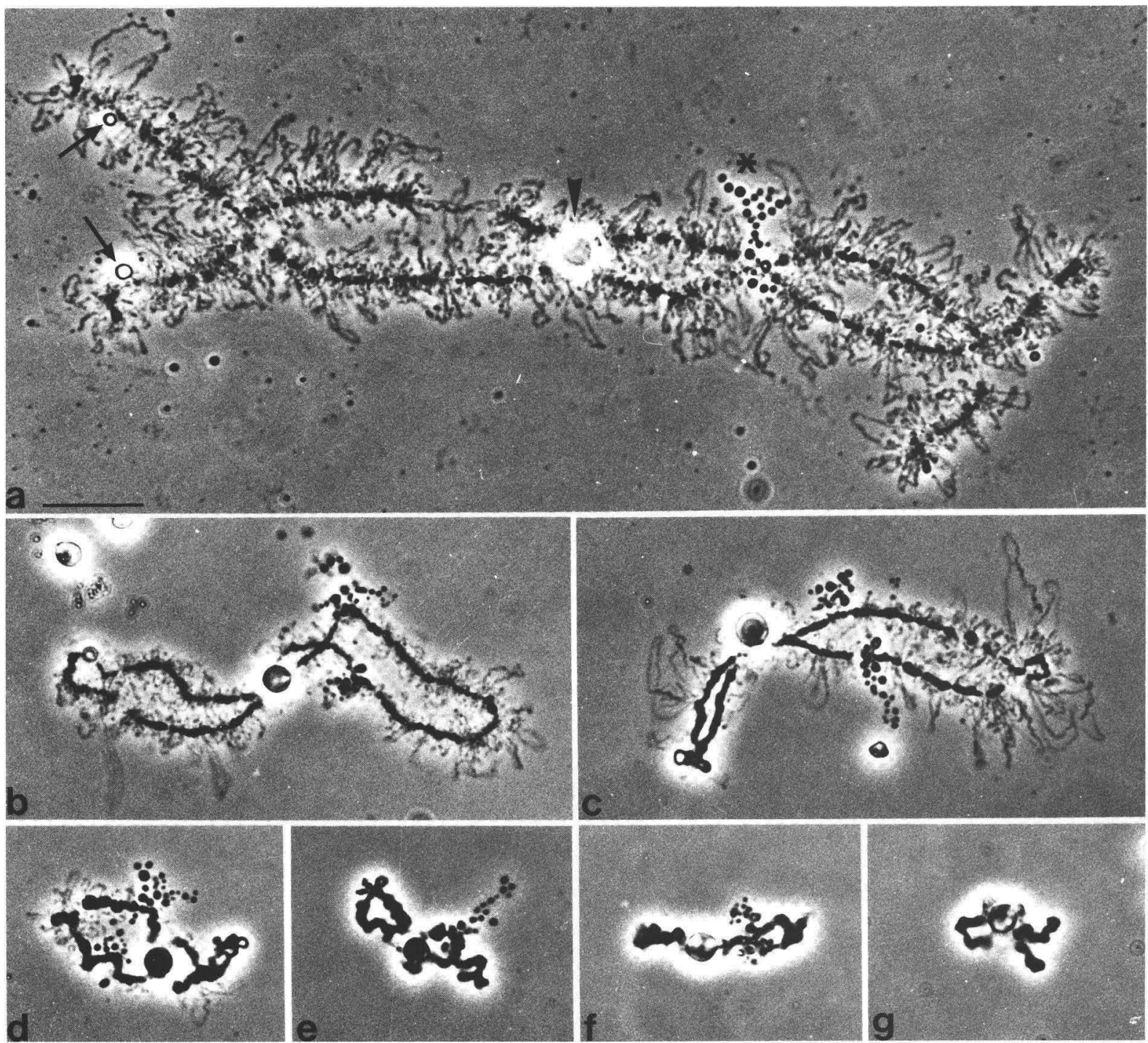

Figure 2. Time Course of Retraction of Lateral Loops of Chromosome Bivalent XI after Injection of Fragmin into Nuclei of Living Pleurodeles Oocytes as Seen by Phase Contrast Microscopy

(a) Chromosome bivalent XI is characterized by three "landmarks" (Lacroix, 1968): a sphere at about the midpoint of the chromosome pair (arrowhead); a pair of granular loops (asterisk); and subterminal nucleolar organizing regions with attached nucleoli (arrows).

(b-f) Chromosome bivalent XI isolated $1 \mathrm{hr}(\mathrm{b}), 1.5 \mathrm{hr}(\mathrm{c}), 2 \mathrm{hr}(\mathrm{d}), 4 \mathrm{hr}(\mathrm{e})$, and $5 \mathrm{hr}$ (f) after injection of fragmin (0.5 mg/ml; $5 \mathrm{nl}$ per nucleus). Retraction of the loops is accompanied by an extensive foreshortening of the chromosomal axes. Note that the granular loop is still visible $5 \mathrm{hr}$ after fragmin injection (f).

(g) Two hours after injection of fragmin-G-actin complexes chromosome bivalent XI is extremely condensed. All lateral loops, including the granular loop, are retracted.

All micrographs are magnified to the same scale. Bar: $20 \mu \mathrm{m}$.

Injection of larger amounts of the antibody solution (10 $\mathrm{nl}$ instead of $5 \mathrm{nl}$ ) caused retraction of the loops of all chromosomes within 4 to $6 \mathrm{hr}$ (Figure 1e). Complete retraction was accompanied by a pronounced foreshortening of the chromosomal axes (see next section). Another preparation of affinity-purified antibodies against actin (lgG) obtained from a different rabbit caused complete loop retraction within $1.5 \mathrm{hr}$ after microinjection $(0.1 \mathrm{mg} / \mathrm{ml} ; 5 \mathrm{nl}$ per nucleus).

\section{Microinjection of Actin-Binding Proteins}

We used an actin-binding protein purified from a slime mold and one purified from mammalian smooth muscle, both of which specifically modulate, in a Ca-dependent manner, the state of polymerization of actin. Fragmin is an actin-binding protein of $M_{r} 42,000$ from the slime mold, Physarum polycephalum, and is known to interact with both F- and G-actin (Hasegawa et al., 1980; Hinssen, 1981a, 1981b). On the one hand, fragmin severs actin 
filaments; on the other hand, it forms very stable heterodimeric complexes with actin monomers. These, in turn, can act as strong nucleation centers for the polymerization of actin and thereby generate a population of short actin filaments that have their fast polymerizing ends capped.

Injection of fragmin at a concentration of $0.5 \mathrm{mg} / \mathrm{ml}$ into nuclei of living amphibian oocytes (i.e. $2.5 \mathrm{ng}$ per nucleus) resulted, within approximately $2 \mathrm{hr}$, in the progressive retraction of most (Figures $2 \mathrm{a}-2 \mathrm{~d}$ ), and within $4-5 \mathrm{hr}$ of all (Figures 2e, 2f), lateral loops. Concomitant with the disappearance of the lateral loops the chromomeric bodies of the chromosome axes coalesced and the chromosomes foreshortened by an average of $\sim 85 \%$ of their initial total lengths (Figures 2e-2f).

Retraction of chromosomal loops was even more rapid when preformed fragmin-G-actin heterodimers, rather than fragmin monomers, were injected into the oocyte nuclei. Two hours after injection the loops of all chromosomes were completely retracted into the highly condensed chromosome axes (Figure $2 \mathrm{~g}$ ).

When fragmin was injected into the cytoplasm, no significant changes of lampbrush chromosome structure were observed. However, the cortical microfilament bundles, including those of the microvilli, were severely affected and disappeared over large parts of the cell surface (not shown).

The mammalian actin modulator from pig stomach smooth muscle (Hinssen et al., 1984) is a protein of $M_{r}$ $\sim 90,000$ that is functionally very similar to fragmin, with the difference that it forms a stable complex with two actin monomers. Microinjection of the pig stomach actin modulator into Pleurodeles oocyte nuclei caused effects similar to those described above for fragmin. When the modulator was injected at a concentration of $1.6 \mathrm{mg} / \mathrm{ml}$ (i.e. approximately $8 \mathrm{ng}$ per nucleus), lampbrush chromosome loops were considerably foreshortened after $1 \mathrm{hr}$ and completely retracted after $2 \mathrm{hr}$ (not shown).

\section{Electron Microscopy of Chromatin from Microinjected Nuclei}

In stages of experimentally induced complete retraction of lateral loops of lampbrush chromosomes (i.e. $6 \mathrm{hr}$ after injection of $10 \mathrm{nl}$ anti-actin lgG; $5 \mathrm{hr}$ after fragmin injection or $2 \mathrm{hr}$ after injection of fragmin-G-actin complexes), electron microscopic spread preparations of nuclear contents consistently revealed large aggregates of transcriptionally inactive chromatin homogeneously arranged in nucleosomes. These probably represent the condensed bodies of the chromosomal axes (Figure 3a). In stages of partial loop retraction some residual loop axes bearing distantly spaced ribonucleoprotein (RNP) transcripts were often found adjacent to the aggregates of transcriptionally inactive chromatin (Figure 3b). Since transcription units of lampbrush loops from untreated oocytes and oocytes receiving control injections are characterized by an extremely high packing density of transcriptional complexes (reviewed in Miller, 1981; Scheer et al., 1979b), their reduced number in injected nuclei indicates premature de- tachment from the loop axes and/or reduced frequency of initiation events. A premature release of transcripts from the template chromatin which in early stages results in intragenic regions without RNP fibrils ("gaps") seems to be a general consequence of reduced transcriptional activity in chromosomal loops (Scheer, 1978; Scheer et al., 1979a, 1979b; Bona et al., 1981; Kleinschmidt et al., 1983).

The transcription of rRNA genes apparently was not affected by the injection of either fragmin, the actin-modulator protein from pig stomach smooth muscle, or antiactin IgG into oocyte nuclei. Typical complete "Christmas tree" structures, characteristic of fully active rRNA genes, were found to the same extent in experimental preparations as in controls (Figure 3c; for correlation of structure and transcriptional activity of rRNA genes see Scheer et al., 1976; Scheer, 1978). This indicates that RNA polymerase II dependent transcription is specifically inhibited by these substances.

\section{RNA Synthesis in Microinjected Oocytes}

We have examined whether the persisting transcription complexes of the rRNA genes seen in electron microscopic spread preparations are indeed fully active. Therefore, we have analyzed by gel electrophoresis the RNA labeled after complete retraction of the lampbrush chromosome loops induced by microinjection of actin antibodies and actin-binding proteins. The results are shown in Figure 4. Oocytes first received intranuclear injections of anti-actin, fragmin, or "actin-modulator protein" from pig stomach smooth muscle. After complete retraction of the lampbrush chromosome loops as judged by light microscopy the oocytes were injected with $\alpha^{-{ }^{32}}$ P-GTP. Five hours later total RNA was extracted from the oocytes and analyzed on $1.5 \%$ agarose gels. As shown in the autoradiogram of Figure 4, rRNA was labeled to approximately the same extent under the experimental (lanes 1-3) and control conditions (lane 4).

Similarly, the radioactivity of the $5 S$ rRNA and tRNA species separated on $6 \%$ polyacrylamide/7 M urea gels was not reduced by microinjection of anti-actin or the actinbinding proteins as compared to controls (not shown).

\section{Changes of the State of Nuclear Actin after Inhibition of Transcription and Digestion of RNP}

In normal lampbrush chromosome preparations, the chromosomes were embedded in a protein-rich nucleoplasmic sol-gel "cloud," in which structural elements could not be distinguished by phase contrast microscopy (Figure 5a). This situation changed dramatically when oocytes were exposed to actinomycin D for several hours before nuclear isolation. As a consequence of the drug-induced inhibition of transcription, the lateral loops of the chromosomes were almost completely retracted (Figure 5b). In addition, the isolated chromosomes were surrounded by a perichromosomal nucleoplasm-derived meshwork of fibrils (Figure $5 b)$. When actinomycin $D$ was removed by incubating the oocytes in large volumes of drug-free medium, the lateral loops progressively reappeared, indicative of re- 


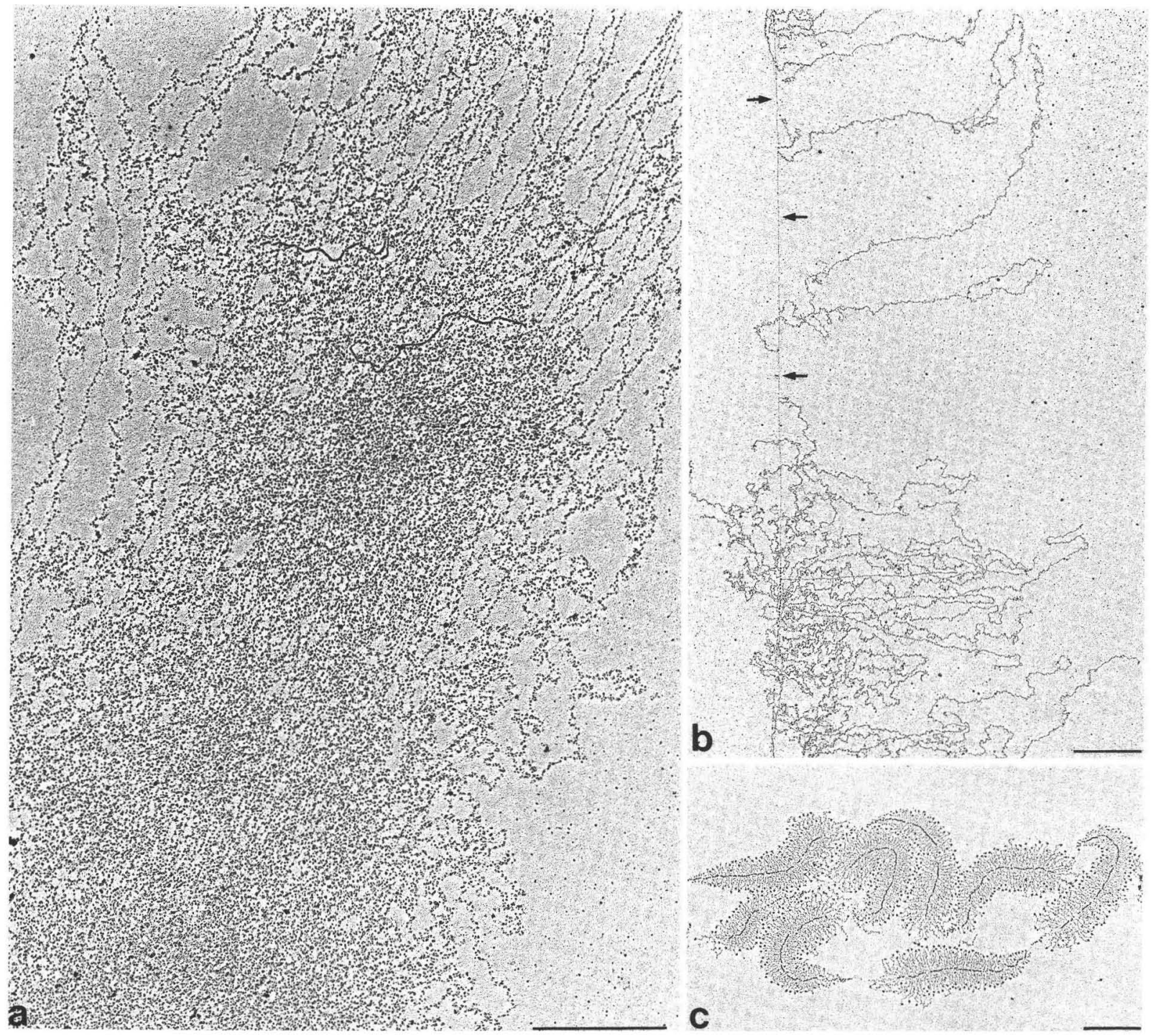

Figure 3. Electron Microscopic Spread Preparations of Chromatin from Lampbrush Chromosomes and Amplified Nucleoli after Intranuclear Injection of Fragmin-G-Actin Complexes and Anti-Actin

(a) $2.5 \mathrm{hr}$ after injection of fragmin-G-actin complexes lampbrush chromosomes occur in form of aggregates of transcriptionally inactive chromatin with the characteristic beaded (nucleosomal) organization.

(b) Intermediate stages of transcriptional inhibition are frequently observed in certain loops after injection of actin antibodies (0.2 mg/ml; $5 \mathrm{nl}$ per nucleus, 5 $\mathrm{hr}$ ). The loop axis is sparsely covered by transcriptional complexes. Some transcript-free regions are denoted by arrows.

(c) rRNA genes appear normal and are fully active as judged from the uninterrupted gradients of nascent transcript-fibrils after injection of fragmin, fragmin$\mathrm{G}$-actin complexes or anti-actin (shown here is a preparation made $5 \mathrm{hr}$ after intranuclear injection of fragmin at a concentration of $0.5 \mathrm{mg} / \mathrm{ml}$ ). Bars: $1 \mu \mathrm{m}$.

newed transcriptional activity. Correspondingly, chromosomes isolated after removal of actinomycin $D$ did not show the perichromosomal meshwork (Figure $5 \mathrm{c}$ ). During normal inactivation of transcription, as in maturing oocytes, a progressive reduction in the size of the lateral loops has been noted (see Scheer et al., 1979b) and chromosomes isolated from these stages are frequently enmeshed in tangles of fibrils.

In experiments in which transcription was inhibited, the presence of the fibrillar meshwork was related to impaired transcription of the lampbrush chromosomes but not of the rRNA genes or polymerase III-dependent genes. This was evident from the finding that after injection of $\alpha$ amanitin into oocytes at concentrations which selectively inhibit the activity of RNA polymerase II (Gurdon and Brown, 1978; Probst et al., 1979; Schultz et al., 1981) the fibril meshwork was found in association with the isolated chromosomes (data not shown). Similar, though more variable, effects have been noted in earlier studies after selective inhibition of transcription of the lampbrush chromosome loops by microinjection of antibodies to histone H2B (Scheer et al., 1979a), RNA polymerase II (Bona et al., 1981), and HMG-1 (Kleinschmidt et al., 1983).

After injection of pancreatic RNAase into oocyte nuclei, 


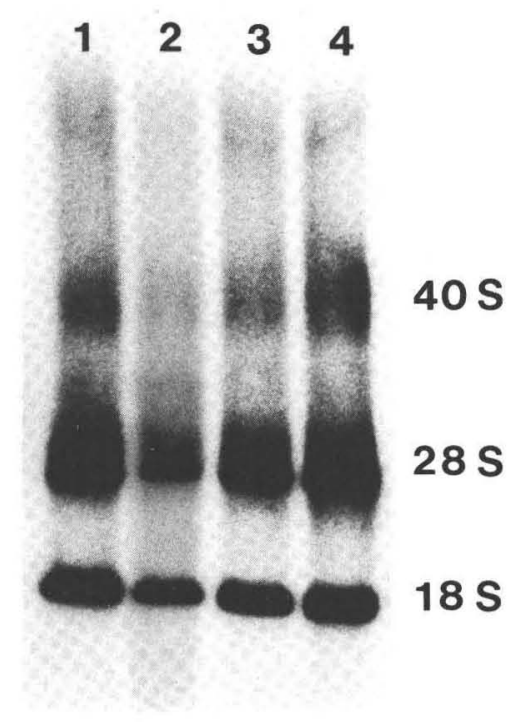

Figure 4. Gel Electrophoresis of RNA from Pleurodeles Oocytes Labeled after Experimentally Induced Retraction of the Lampbrush Chromosome Loops as Seen by Autoradiography

Anti-actin (lane 1), fragmin (lane 2), and actin modulator (lane 3) were injected into the nuclei of centrifuged oocytes. Control oocytes (lane 4) received equal volumes of the injection buffer. After retraction of the chromosome loops as judged by light microscopy of chromosome preparations, each oocyte received an intranuclear injection of $0.1 \mu \mathrm{Ci} \alpha^{32} \mathrm{P}$. GTP. RNA was extracted $5 \mathrm{hr}$ later and analyzed on $1.5 \%$ agarose gels. RNA corresponding to three oocytes was applied to each gel lane.

the lateral loops of the lampbrush chromosomes disappeared within a very short time (10 to $20 \mathrm{~min}$ ), probably as a consequence of digestion of the attached nascent RNP fibrils (Figure 5d). Again, the isolated chromosomes were embedded in an extended fibril network (Figure 5d; see also Callan, 1982).

In order to elucidate the nature of the perichromosomal fibrils formed from nucleoplasmic protein material upon inhibition of transcription or digestion of RNP, we used three different methods. One was immunofluorescence microscopy. The fibrils reacted strongly with antibodies to actin (Figures 6a, 6c). Amplified nucleoli present in the same preparation were completely negative, whereas the axial structures of the chromosomes revealed a weak,

Figure 5. Induction of a Perichromosomal Meshwork of Fibrillar Bundles after Inhibition of Transcription by Actinomycin D and after Intranuclear Injection of RNAase as Seen by Phase Contrast Microscopy

(a) Control chromosome bivalent from a growing Pleurodeles oocyte. No formed elements other than amplified nucleoli (arrow) and small granules are visible in the vicinity of the chromosomes.

(b) Chromosome preparation $6 \mathrm{hr}$ after incubation of intact Pleurodeles oocytes in medium containing $50 \mu \mathrm{g} / \mathrm{ml}$ actinomycin D. Lateral loops are retracted, and the chromosome bivalent is surrounded by a dense network of fibrils.

(c) Oocytes were first exposed to actinomycin D as described above and were then incubated for $20 \mathrm{hr}$ in medium without the drug. Lateral loops have partly recovered and the amount of the perichromosomal fibrillar bundles is drastically reduced (a few fibrils are denoted by arrows).

(d) Chromosome preparation 20 min after intranuclear injection of pancreatic RNAase $(100 \mu \mathrm{g} / \mathrm{ml} ; 5 \mathrm{nl}$ per nucleus, i.e. final nuclear concentration approximately $10 \mu \mathrm{g} / \mathrm{ml})$. Chromosomes with collapsed loops are surrounded by fibrillar network. Bars: $20 \mu \mathrm{m}$.
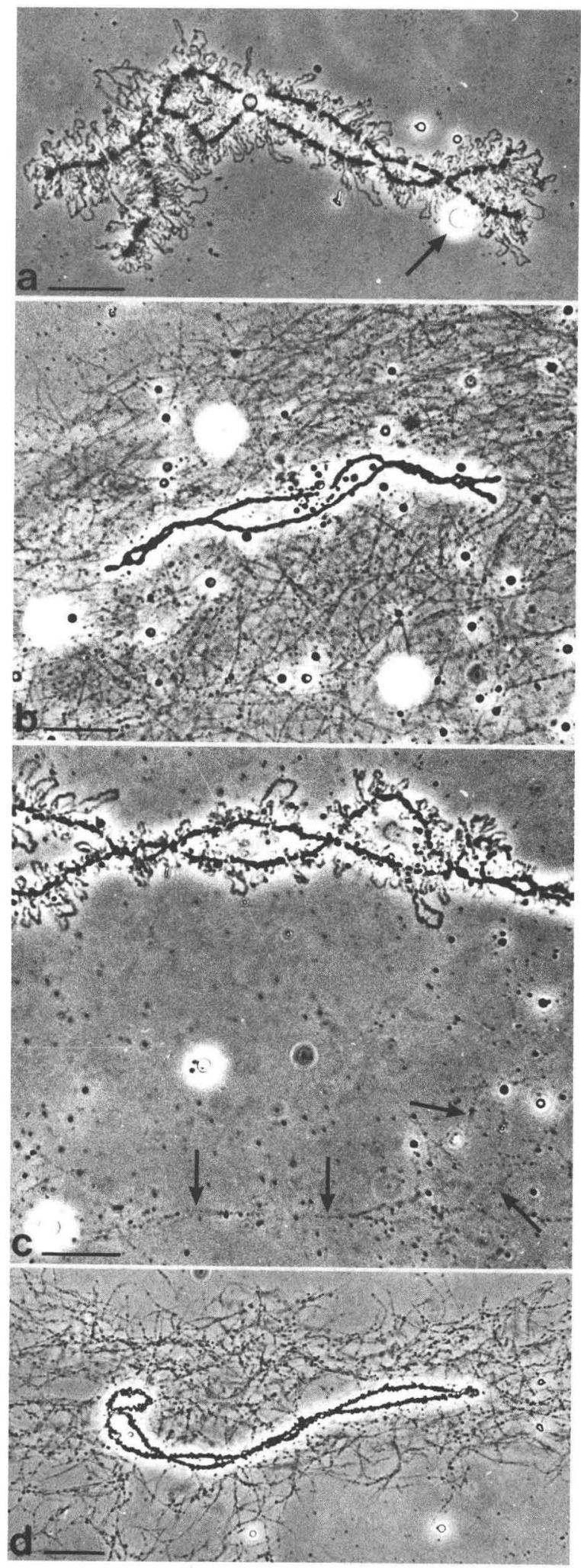
sometimes punctate fluorescence that could be attributed to the presence of some actin-containing material on the surfaces of certain chromomeres (Figure 6c; see also Karsenti et al., 1968). The second method was electron microscopy. Thin sections through such perichromosomal fibril meshwork revealed bundles of $5 \mathrm{~nm}$ microfilaments with associated electron-dense particles (Figure 6e). The third was drug treatment. After incubation of oocytes in medium containing actinomycin $D$ for $6 \mathrm{hr}$ in order to induce the nuclear filament bundles, the F-actin-severing protein fragmin was injected into the nuclei 10 min prior to their isolation. Phase contrast microscopy revealed that the perichromosomal fibrils were completely absent after this treatment (not shown).

These observations indicate that the filament bundles observed during natural or experimentally induced transcriptional inactivation of the lampbrush chromosomes of Pleurodeles represent F-actin bundles, similar to those reported in freshly isolated Xenopus oocyte nuclei (Clark and Rosenbaum, 1979) and in isolated oocyte nuclei of Pleurodeles incubated with phalloidin (Gounon and Karsenti, 1981).

\section{Control Experiments}

To examine the possibility that retraction of the chromosomal loops was due to traces of nucleolytic or proteolytic enzymes present as contaminations in the solutions injected, a series of control injections was performed. Diverse immunoglobulin preparations were purified by column chromatography on DEAE-cellulose, frequently followed by affinity chromatography (similar to the method used for the purification of anti-actin $\lg$ G), and were dissolved in Tris-buffered saline prior to intranuclear injection. Injections (5 nl per nucleus) of the following were without any noticeable effect on lampbrush chromosome morphology: nonimmune immunoglobulins or IgG prepared from rabbit, guinea pig, mouse and human sera (1-1.5 $\mathrm{mg} / \mathrm{ml})$; rabbit anti-tubulin $(0.2 \mathrm{mg} / \mathrm{ml})$; rabbit anti- $\alpha$-actinin $(0.2 \mathrm{mg} / \mathrm{ml})$; rabbit anti-tropomyosin $(0.2 \mathrm{mg} / \mathrm{ml})$; rabbit anti-calmodulin $(0.1 \mathrm{mg} / \mathrm{ml})$; guinea pig anti-nucleoplasmin $(1.5 \mathrm{mg} / \mathrm{ml})$; guinea pig anti-protein N1/N2 from Xenopus oocyte nuclei $(1.5 \mathrm{mg} / \mathrm{ml})$. Nucleoplasmin and N1/N2 are, together with actin, the most abundant protein classes in

Figure 6. Analysis of the Actinomycin D Induced Fibrillar Bundles by Immunofluorescence Microscopy by Using Antibodies to Actin and by Electron Microscopy

(a-d) Pleurodeles oocytes were incubated in medium containing actinomycin D $(50 \mu \mathrm{g} / \mathrm{ml}, 6 \mathrm{hr})$ followed by chromosome preparation. After centrifugation $(2000 \mathrm{rpm} \times 10 \mathrm{~min}$ ) the specimens were incubated with affinity-purified anti-actin lgG $(10 \mu \mathrm{g} / \mathrm{ml})$ followed by FITC-labeled goat antirabbit lgG (1:500). The filament bundles show strong fluorescence $(a$, and c, corresponding phase contrast micrographs shown in b and d). Lateral loops of the chromosomes are retracted and the chromosomal axes reveal only occasional weak fluorescence (c).

(e) Electron micrograph of ultrathin section of flat-embedded filament induced by incubating the oocytes with actinomycin D. Note parallel microfilaments (arrows) with associated dense granules. Bars: $10 \mu \mathrm{m}$ (b, d) and $0.1 \mu \mathrm{m}(\mathrm{e})$.
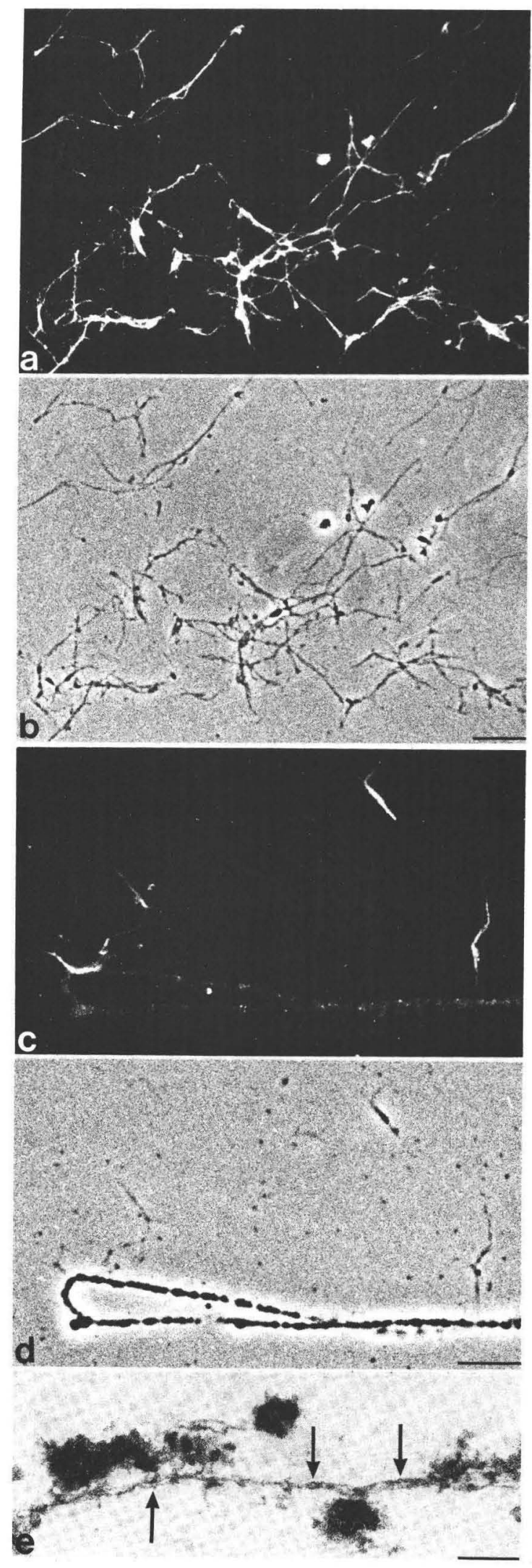
nuclei of amphibian oocytes (Krohne and Franke, 1980a, 1980b; Dabauvalle and Franke, 1982). Thus nonspecific side effects of the injected immunoglobulins and/or of the injection procedure itself can be excluded.

Furthermore, the kinetics of action of microinjected RNAase were totally different from the relatively slow retraction process of the loops observed after injection of actin-binding proteins or anti-actin antibodies: within 1020 min after injection of RNAase to a final nuclear concentration of $10 \mu \mathrm{g} / \mathrm{ml}$ all lateral loops were collapsed onto the chromosome axes, concomitant with the induction of a meshwork of filament bundles (Figure $5 \mathrm{~d}$ ). Injection of DNAase I, on the other hand, resulted in breaks in the lateral loops (Figure 7a) and occasionally in chromosome axes. It is also worth mentioning in this context that the lampbrush chromosomes were highly resistant to the action of DNAase I in the living cell. Thus injection of DNAase I to an intranuclear concentration of $100 \mu \mathrm{g} / \mathrm{ml}$ was necessary to break a significant number of the loops within 20 min (Figure 7a). In contrast, isolated lampbrush chromosomes were much more susceptible to the action of DNAase I (not shown; see also previous work of McGregor and Callan, 1962; Gall, 1963). It is likely that this reduced efficiency of DNAase I within the nucleus is due to the large amount of G-actin present in oocyte nuclei, which could be expected to bind and inactivate the injected DNAase I (Lazarides and Lindberg, 1974; c.f. Clark and Merriam, 1977; Gounon and Karsenti, 1981).

We also injected a number of proteins other than immunoglobulins, including bovine and rabbit serum albumin, Xenopus nucleoplasmin, rabbit hemoglobin (all at a concentration of $1-1.5 \mathrm{mg} / \mathrm{ml}$; not shown), and rabbit skeletal muscle G-actin (Figure $7 \mathrm{~b}$ ). With none of these proteins did we find a significant change of loop morphology. The only remarkable change was observed after injection of relatively large amounts of G-actin (5 ng per nucleus), which resulted in the formation of an extended fibril meshwork around the isolated lampbrush chromosomes (Figure $7 b)$.

The actin-binding proteins were routinely injected in the presence of 0.1 or $0.5 \mathrm{mM} \mathrm{CaCl}_{2}$ since they require micromolar amounts of free $\mathrm{Ca}^{2+}$ for their activity (Hasegawa et al., 1980; Hinssen, 1981b; Hinssen et al., 1984). In order to evaluate the effect of divalent cations on chromosomal morphology, $\mathrm{CaCl}_{2}$ alone was injected. As shown in Figure $7 \mathrm{c}$, the chromosomes appeared identical to control preparations.

In order to examine possible effects of induced polymerization of nuclear actin on transcription, we microinjected phalloidin $(1 \mathrm{mg} / \mathrm{ml})$, a mushroom drug known to stabilize and arrest the polymer form of actin (Wieland and Faulstich, 1978), into nuclei of living oocytes. This resulted in the instantaneous "hardening" of the whole nuclear content (not shown). This is in agreement with the observations made by Gounon and Karsenti (1981) after incubation of isolated nuclei with phalloidin. Such phalloidin-altered nuclei did not allow the spreading and visualization of the loops of lampbrush chromosomes. To allow visualization of the

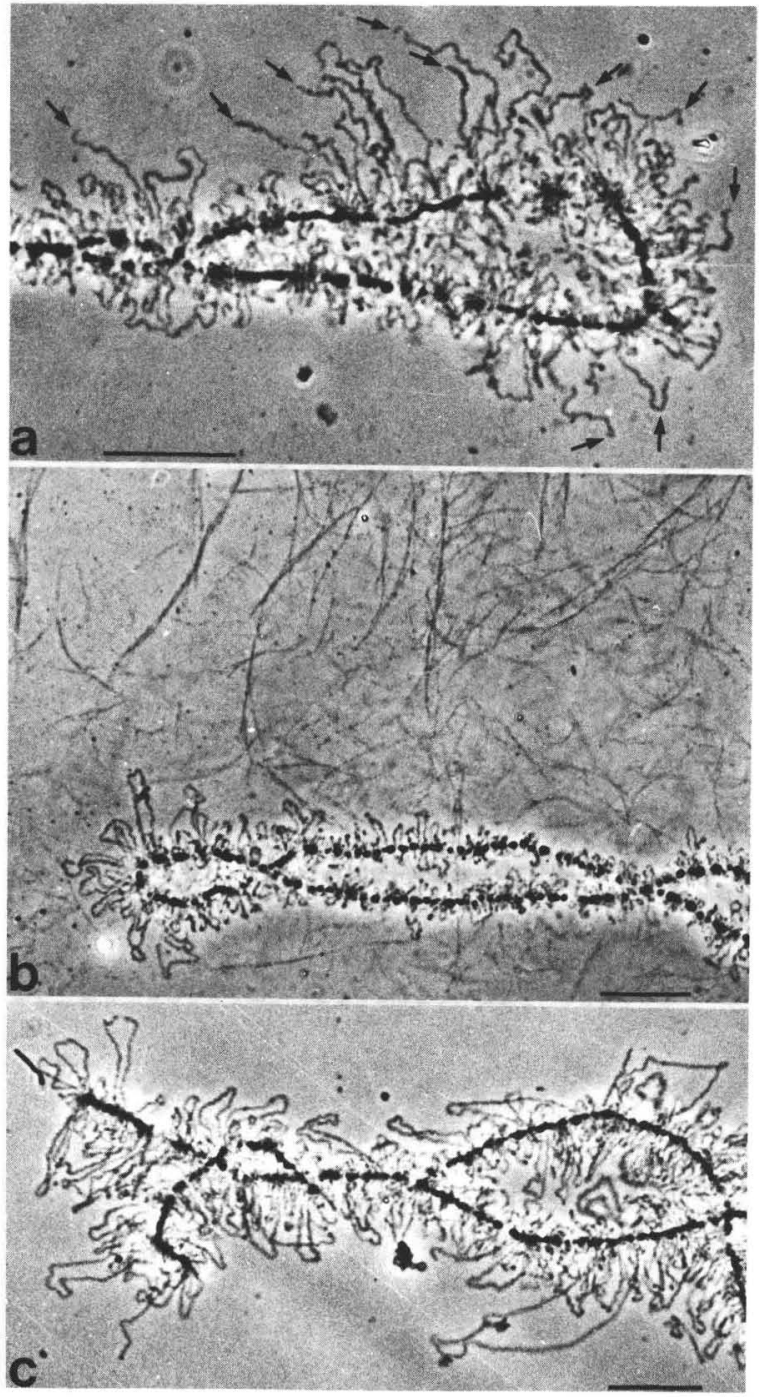

Figure 7. Appearance of Lampbrush Chromosomes and the Surrounding Perichromosomal Material (Phase Contrast Microscopy) after Injection of Various Control Solutions into the Nuclei of Living Pleurodeles Oocytes

(a) Part of a chromosomal bivalent 30 min after injection of DNAase I (1 $\mathrm{mg} / \mathrm{ml} ; 5 \mathrm{nl}$ per nucleus, i.e. final nuclear concentration approximately 100 $\mu \mathrm{g} / \mathrm{ml}$ ). Many loops are disrupted and free ends are visible (arrows).

(b) Injection of G-actin $(0.9 \mathrm{mg} / \mathrm{ml})$ often results in the appearance of fibrillar meshwork surrounding the lampbrush chromosomes which maintain their extended lateral loops.

(c) Injection of $\mathrm{CaCl}_{2}$ ( $1 \mathrm{mM} ; 5 \mathrm{nl}$ per nucleus, i.e. approximately $0.1 \mathrm{mM}$ final nuclear concentration) does not alter the appearance of the chromosomes and filaments are not visible ( $3 \mathrm{hr}$ after injection). Bars: $20 \mu \mathrm{m}$.

chromosomes, fragmin was microinjected into nuclei which had been injected $4 \mathrm{hr}$ earlier with phalloidin. This resulted, within $10 \mathrm{~min}$, in a restoration of the initial low viscosity state of the nucleoplasm, probably as a result of the actin filament severing activity of fragmin. Chromosomes observed after this sequential treatment with phalloidin ( $4 \mathrm{hr}$ ) and fragmin (10 $\mathrm{min}$ ) showed largely retracted loops but no chromosome compaction. This finding is compatible with an involvement of nonpolymer actin in transcription 
but, of course, does not prove it, as the effects of phalloidin on chromosomal structure may be more indirect.

\section{Discussion}

We propose a novel role for the widespread cell protein actin, probably unexpected by most biologists working on this protein. Our results indicate that at least part of the nuclear actin is involved in the transcription of chromosome loops containing genes coding for proteins. The assay used to demonstrate this involvement, i.e. injection of substances into nuclei of living cells, has repeatedly proved to be a valuable assay of diverse nuclear functions, compatible with cell viability and the continuation of nuclear activities (e.g. Graessmann and Graessmann, 1976; Mertz and Gurdon, 1977; DeRobertis and Mertz, 1977; Trendelenburg et al., 1978; Gurdon and Melton, 1981; SollnerWebb and McKnight, 1982; Etkin, 1982; Renkawitz et al., 1982; Green et al., 1983; Birchmeier et al., 1984). In particular, the selective inhibition of transcriptional events mediated by RNA polymerase II has already been demonstrated by microinjection of antibodies to RNA polymerase II (Bona et al., 1981) and also by antibodies to histones and HMG proteins (Scheer et al., 1979a; Einck and Bustin, 1983; Kleinschmidt et al., 1983). Various control injections have not produced such changes in chromosome morphology (this study and Bona et al., 1981), indicating that a leakage of solutions, which in general can occur during microinjection of amphibian oocytes (Miller et al., 1984), is not responsible for the specific effects observed. Therefore, we consider our observation that injection of antibodies against actin results in the cessation of transcription by RNA polymerase $\|$, loop retraction, and chromosome condensation to be significant. Moreover, our finding that the same phenomenon occurs, even more dramatically, upon injection of actin-binding proteins from different sources, as fragmin from Physarum polycephalum and the actin modulator protein from mammalian smooth muscle, shows that this inhibition of transcription is indeed related to the interference with actin and is not an artifact due to the presence of actin antibodies. The specificity of the actin involvement in RNA polymerase II-mediated transcription is also evident from our demonstration that nucleolar transcription by RNA polymerase I continues in the presence of both actin antibodies and the actin-binding proteins.

A more detailed discussion of the various effects of microinjected actin antibodies and actin modulators has to take into account their specific ways of interaction with actin in vitro. Our data show that the concentration of injected actin antibodies effective in inhibition of transcription is much lower than that of the endogenous actin (ratio approximately 1:400). This suggests that not all nuclear actin is involved in transcription but only a small proportion that reacts more avidly with the antibodies. Alternatively, in the nucleus the actin antibodies may bind preferentially to the growing ends of short actin polymers and thus interfere with the polymerization equilibrium at very low concentrations.

In the case of the actin modulators, fragmin, and the smooth muscle protein, several possibilities have to be considered because of the complex pattern of their interaction with actin. On the one hand, a simple inactivation of actin monomers by formation of a stoichiometric complex with the injected modulator seems unlikely because the effective amount of modulator injected is in a substoichiometric ratio with respect to the total actin present in the nucleus (approximately 1:50). The marked effects of the modulators at substoichiometric concentrations indicate that the polymerization process or preexisting polymer forms of actin are somehow involved. On the other hand, a direct severing of preexisting actin filaments by these modulators seems to be excluded as the nonsevering 1:1 complex of actin and fragmin (Hinssen, 1981b) also inhibits transcription when microinjected. Therefore, we consider a nucleating and capping effect on actin polymerization to be the most likely mechanism. Two possibilities may be envisaged: the nucleating effect on a large pool of G-actin which is eventually stabilized in its monomeric state by profilin or similar proteins, and the introduction of many new nucleating and capping sites into a system of actin filaments which would gradually depolymerize by a turnover mechanism via a relatively small G-actin pool. The final stage in both mechanisms is a population of short actin filaments and oligomers, which in the first case means a dramatically reduced amount of unpolymerized actin and in the second case a breakdown of preexisting filamentous structural elements.

From the experimental approach we have used in this study we cannot definitely decide whether or not the actin involved in the transcriptional events includes actin polymers. So far studies of the biological functions of actin such as contractile processes and gel formation have predominantly dealt with its polymerized state (see Introduction). However, many observations point to the existence of monomeric or oligomeric actin in the nucleus, and there may be functions of actin that are not dependent on filament formation. Actin microfilaments, the usual form of actin polymers, have not yet been shown to exist in intact nuclei of normal, transcriptionally active cells, although such filaments are clearly demonstrable in the nucleoplasm after treatment of cells with dimethyl sulfoxide (Fukui, 1978; Sanger et al., 1980; Wehland et al., 1980) or with drugs that inhibit transcription (Lane, 1969) and in isolated nuclei (Clark and Rosenbaum, 1979; Gounon and Karsenti, 1981). We have also shown in this study that extended meshworks of actin microfilaments are formed in the vicinity of the lampbrush chromosomes upon inactivation of transcriptional activity.

Though it cannot be excluded that actin microfilaments are critically involved in the positioning and nucleocytoplasmic translocation of ribonucleoprotein products, as proposed by several authors (Gounon and Karsenti, 1981; Reddy and Busch, 1983), the data presented in this study are also compatible with concepts involving monomeric or 
oligomeric nuclear actin in the transcriptional process. This idea is supported by earlier findings that actin is tenaciously associated with purified RNA polymerase II (Smith et al., 1979) and that correct initiation of transcription by polymerase II in vitro requires a protein factor that recently has been shown to contain $\beta$ - and $\gamma$-actin (Egly et al., 1984). In addition, recent evidence has indicated that G-actin may be involved in the regulation of the poly $(A)$ metabolism, mediated by the enzyme poly(A)polymerase (Schröder et al., 1982). Finally, we have to consider another hypothesis-namely, that nuclear actin in such high concentrations contributes to the formation of a colloidal protein milieu in the nucleoplasm which is essential for the transcriptional process and the three-dimensional organization of the chromosome loops.

Our observations can only be taken as a first hint of the possibility of a new role for nuclear actin. Further experiments are necessary to identify the specific mode in which actin is involved in transcription of protein-coding genes.

\section{Experimental Procedures}

\section{Oocytes and Microinjection}

The salamanders, Pleurodeles waltlii, were reared in our laboratory. Pieces of ovary were removed from anesthetized $(0.1 \%$ MS 222; Serva, Heidelberg, FRG) females and placed in modified Barth medium (Gurdon, 1976) containing 50 units $/ \mathrm{ml}$ each of penicillin and streptomycin. Growing oocytes with diameters from 1.2 to $1.4 \mathrm{~mm}$ were mechanically freed from their surrounding follicle epithelium, placed onto a nylon net with the animal pole facing upward, and centrifuged at 200-250 $\times$ g for 20-30 min until the nucleus reached the plasma membrane and became visible as a clear roundish zone within the dark animal hemisphere. Usually, nuclei were each injected with approximately $5 \mathrm{nl}$ solution (i.e. roughly one tenth of the nuclear volume) using a low power micromanipulator (MK I, Singer Instrument Company, Treborough Lodge, Roadwater, England). For some experiments small ovary pieces were incubated for $6 \mathrm{hr}$ in Barth medium containing $50 \mu \mathrm{g} / \mathrm{ml}$ actinomycin D (Serva, Heidelberg, FRG).

\section{Actin Antibodies and Actin-Binding Proteins}

Antibodies against chicken gizzard actin were raised in rabbits and purified by affinity chromatography as described (Jockusch et al., 1978). For microinjection, they were dissolved in PBS at a concentration of $0.2 \mathrm{mg} /$ $\mathrm{ml}$. In immunoblots of two-dimensional SDS-polyacrylamide gels this antibody reacted exclusively with $\beta$ - and $\gamma$-actin prepared from low ionic strength extracts of acetone powdered chicken gizzard (data not shown).

Fragmin was purified from the slime mold Physarum polycephalum as outlined by Hinssen (1981a). Prior to microinjection the fragmin solution was adjusted to a concentration of $0.5 \mathrm{mg} / \mathrm{ml}$ and dialyzed against " $3: 1$. saline" ( $75 \mathrm{mM} \mathrm{KCl}, 25 \mathrm{mM} \mathrm{NaCl}, 10 \mathrm{mM}$ Tris-HCl, pH 7.2) containing 0.5 $\mathrm{mM} \mathrm{CaCl}$. Heterodimeric complexes between fragmin and $\mathrm{G}$-actin were reconstituted by adding G-actin from rabbit skeletal muscle to fragmin $(0.5$ $\mathrm{mg} / \mathrm{ml}$ ) in a weight ratio of 1:1 (Hinssen, 1981b). The mixture was dialyzed as described above prior to its microinjection.

The actin modulator from pig stomach smooth muscle was purified according to Hinssen et al. (1984). The solution used for injection contained $1.6 \mathrm{mg} / \mathrm{ml}$ in "3:1-saline" with $0.1 \mathrm{mM} \mathrm{CaCl}$.

\section{Control Injections}

Immunoglobulin (Ig) fractions from diverse sera were obtained by column chromatography on DEAE-cellulose (DE 52, Whatman; Bustin et al., 1977). The $\mathrm{lg}$ fraction in the early eluting peak was concentrated and finally dissolved in PBS or "3:1-saline" at concentrations ranging from 1 to $2 \mathrm{mg} /$ $\mathrm{ml}$. Several Ig fractions were further purified by affinity chromatography.

Ig fractions were prepared from nonimmune sera of rabbits, guinea pigs, mice, and humans. Nonimmune $\lg G$ from the same species were purchased from Miles (Frankfurt, FRG). The following specific antibodies were injected: anti-tubulin and anti-calmodulin prepared against porcine brain tubulin (Jockusch et al., 1979; Hauser et al., 1980) and against calmodulin (Hauser and Jockusch, unpublished data) respectively; anti-tropomyosin and anti$\alpha$-actinin prepared against chicken gizzard tropomyosin (Boschek et al., 1981 ) and porcine skeletal muscle $\alpha$-actinin (Hoessli et al., 1980; Sixma et al., 1982). All antibodies were raised in rabbits and were purified on Sepharose $4 \mathrm{~B}$ linked to the corresponding antigen. Antibodies to nucleoplasmin and the karyophilic proteins N1/N2 from Xenopus laevis oocyte nuclei were raised in guinea pigs (Krohne and Franke, 1980a, 1980b; Kleinschmidt et al., 1984). The antibodies against smooth muscle actin and tropomyosin as well as the antibody against skeletal muscle $\alpha$-actinin had been shown previously to cross-react extensively with the corresponding non-muscle antigens (see, for example, Jockusch et al., 1977, 1978, 1983; Hauser et al., 1980; Boschek et al., 1981; Sixma et al., 1982).

DNAase I, pancreatic RNAase, and phalloidin were obtained from Boehringer (Mannheim, FRG); bovine and rabbit serum albumin and rabbit hemoglobin from Sigma Chemie (Taufkirchen, FRG). G-actin was prepared from rabbit skeletal muscle following the procedure described by Pardee and Spudich (1982) and dialyzed against $2 \mathrm{mM}$ Tris-HCl (pH 8.0), 0.2 mM $\mathrm{CaCl}_{2}, 0.2 \mathrm{mM}$ ATP prior to injection. Nucleoplasmin was purified from $\mathrm{X}$. laevis ovary as described by Dingwall et al. (1982).

\section{Light Microscopy of Lampbrush Chromosomes and} Perichromosomal Material

Individual oocytes were placed in "3:1-saline," and the nuclei were isolated manually and transferred into a observation chamber containing the same buffer adjusted to $0.1 \mathrm{mM} \mathrm{CaCl}_{2}$ (Callan and Lloyd, 1960). After the nuclear envelope was removed mechanically, the nuclear content was allowed to disperse and to spread to the bottom of the observation chamber. After approximately $1 \mathrm{hr}$ the chamber was centrifuged $(800 \times \mathrm{g}, 10 \mathrm{~min})$ in order to anchor the chromosomes and the perichromosomal material firmly to the bottom of the chamber. Photographs were taken with phase contrast optics (40x) using an inverted Zeiss microscope IM 35 equipped with a flash. Inclusion of $2 \mathrm{mM}$ dithiothreitol (DTT) in the medium did not change the results.

\section{Electron Microscopy}

Lampbrush chromosomes prepared as described above were fixed in $2.5 \%$ glutaraldehyde containing $75 \mathrm{mM} \mathrm{KCl}, 25 \mathrm{mM} \mathrm{NaCl}$, and $50 \mathrm{mM}$ cacodylate buffer $(\mathrm{pH} 7.2)$, at $4^{\circ} \mathrm{C}$ for $15 \mathrm{~min}$. Then the specimens were washed several times in cacodylate buffer, postfixed in $2 \% \mathrm{OsO}_{4}\left(10 \mathrm{~min}, 4^{\circ} \mathrm{C}\right)$, washed in distilled water and impregnated overnight in $0.5 \%$ aqueous uranyl acetate. After dehydration through graded ethanol solutions the specimens were embedded in Epon 812 as described (Spring and Franke, 1981). Ultrathin sections were stained according to standard procedures. Chromatin spread preparations were made essentially according to the method of Miller and Bakken (1972) with some modifications (Scheer, 1978; Scheer et al., 1976, 1979a, 1979b). Electron micrographs were taken with a Zeiss EM 10A.

\section{Immunofluorescence Microscopy}

Lampbrush chromosomes and perichromosomal material prepared as described above were incubated with affinity-purified anti-actin lgG dissolved in PBS at a concentration of $10 \mu \mathrm{g} / \mathrm{ml}$ for $10 \mathrm{~min}$. After several washes in PBS, FITC-labeled goat anti-rabbit IgG (Miles-Yeda, Rehovot, Israel; diluted 1:500) was added for another $10 \mathrm{~min}$. Following several washes in PBS, the coverslip forming the bottom of the chamber and containing the chromosomes and perichromosomal material was removed and mounted in Elvanol. Photographs were taken with a Zeiss photomicroscope III equipped with epifluorescence optics. Control preparations with nonimmune lgG $(20 \mu \mathrm{g} / \mathrm{ml})$ instead of anti-actin lgG were completely negative.

\section{RNA Analysis}

RNA was labeled by microinjection of $0.1 \mu \mathrm{Ci}\left(\alpha^{-32}\right)$ GTP $(10 \mathrm{mCi} / \mathrm{ml}$; Amersham Buchler, Braunschweig, FRG) into the nucleus of each oocyte. After $5 \mathrm{hr}$ at $20^{\circ} \mathrm{C}$ in Barth medium, oocytes (10 per experimental group) were homogenized in $0.7 \mathrm{ml}$ of a buffer containing $50 \mathrm{mM}$ Tris-HCl $(\mathrm{pH}$ 7.6), $20 \mathrm{mM} \mathrm{NaCl}, 1 \% \mathrm{SDS}$ and extracted with phenol/chloroform/isoamyl alcohol as described (Scheer et al., 1976). RNA was analyzed by electrophoresis on $1.5 \%$ agarose gel slabs. Dried gels were exposed to Kodak $X$ Omat films at $-70^{\circ} \mathrm{C}$. Ribosomal RNA extracted from $\mathrm{X}$. laevis ribosomes, 
tobacco mosaic virus RNA, and tRNA from E. coli were run on the same gel as molecular weight markers and were identified after staining with ethidium bromide.

\section{Acknowledgments}

We are grateful to Dr. Georg Krohne for antibodies against nucleoplasmin and N1/N2 and to Thomas Ankenbauer for G-actin. We thank Ch. Wiegand for excellent technical assistance. This work received financial support from the Volkswagen-Stiftung and the Deutsche Forschungsgemeinschaft (grant Sche 157/5-3). H. H. is recipient of a Heisenberg fellowship from the Deutsche Forschungsgemeinschaft.

The costs of publication of this article were defrayed in part by the payment of page charges. This article must therefore be hereby marked "advertisement" in accordance with 18 U.S.C. Section 1734 solely to indicate this fact.

Received May 29, 1984; revised August 14, 1984

\section{References}

Birchmeier, C., Schümperli, D., Sconzo, G., and Birnstiel, M. L. (1984). 3' Editing of mRNAs: sequence requirements and involvement of a 60 nucleotide RNA in maturation of histone mRNA precursors. Proc. Nat. Acad. Sci. USA 81, 1057-1061.

Bona, M., Scheer, U., and Bautz, E. K. F. (1981). Antibodies to RNA polymerase || (B) inhibit transcription in lampbrush chromosomes after microinjection into living amphibian oocytes. J. Mol. Biol. 151, 81-99.

Boschek, C. B., Jockusch, B. M., Friis, R. R., Back, R., Grundmann, E., and Bauer, H. (1981). Early changes in the distribution and organization of microfilament proteins during cell transformation. Cell 24, 175-184.

Bustin, M., Simpson, R. T., Sperling, R., and Goldblatt, D. (1977). Molecular homogeneity of the histone content of HeLa chromatin subunits. Biochemistry $16,5381-5385$.

Callan, H. G. (1982). Lampbrush chromosomes. Proc. Royal Soc. Lond. B. 214, 417-448.

Callan, H. G., and Lloyd, L. (1960). Lampbrush chromosomes of crested newts Triturus cristatus (Laurenti). Phil. Trans. Royal Soc. Lond. B. 243, 17-219

Clark, T. G., and Merriam, R. W. (1977). Diffusible and bound actin in nuclei of Xenopus laevis oocytes. Cell 12, 883-891.

Clark, T. G., and Rosenbaum, J. L. (1979). An actin filament matrix in handisolated nuclei of $\mathrm{X}$. laevis oocytes. Cell 18, 1101-1108.

Comings, D. E., and Harris, D. C. (1976). Nuclear proteins. II. Similarity of nonhistone proteins in nuclear sap and chromatin, and essential absence of contractile proteins from mouse liver nuclei. J. Cell Biol. 70, 440-452.

Dabauvalle, M.-C., and Franke, W. W. (1982). Karyophilic proteins: polypeptides synthesized in vitro accumulate in the nucleus on microinjection into the cytoplasm of amphibian oocytes. Proc. Nat. Acad. Sci. USA 79, 5302-5306

DeRobertis, E. M., and Mertz, J. E. (1977). Coupled transcription-translation of DNA injected into Xenopus oocytes. Cell 12, 175-182.

DeRobertis, E. M., Longthorne, R. F., and Gurdon, J. B. (1978). Intracellular migration of nuclear proteins in Xenopus oocytes. Nature 272, 254-256.

Dingwall, C., Sharnick, S. V., and Laskey, R. A. (1982). A polypeptide domain that specifies migration of nucleoplasmin into the nucleus. Cell 30 , 449-458.

Douvas, A. S., Harrington, C. A., and Bonner, J. (1975). Major nonhistone proteins of rat liver chromatin: preliminary identification of myosin, actin, tubulin, and tropomyosin. Proc. Nat. Acad. Sci. USA 72, 3902-3906.

Egly, J. M., Miyamoto, N., Moncollin, V., and Chambon, P. (1984). Is actin a transcription initiation factor for RNA polymerase B? EMBO J., in press.

Einck, L., and Bustin, M. (1983). Inhibition of transcription in somatic cells by microinjection of antibodies to chromosomal proteins. Proc. Nat. Acad. Sci. USA 80, 6735-6739.
Etkin, L. D. (1982). Analysis of the mechanisms involved in gene regulation and cell differentiation by microinjection of purified genes and somatic cell nuclei into amphibian oocytes and eggs. Differentiation 21, 149-159.

Franke, W. W., Rathke, P. C., Seib, E., Trendelenburg, M. F., Osborn, M., and Weber, K. (1976). Distribution and mode of arrangement of microfilamentous structures and actin in the cortex of the amphibian oocyte. Cytobiol. 14, 111-130

Fukui, Y. (1978). Intranuclear actin bundles induced by dimethyl sulfoxide in interphase nucleus of Dictyostelium. J. Cell Biol. 76, 146-157.

Gall, J. G. (1963). Kinetics of deoxyribonuclease action on chromosomes. Nature 198, 36-38.

Gall, L., Picheral, B., and Gounon, P. (1983). Cytochemical evidence for the presence of intermediate filaments and microfilaments in the egg of Xenopus laevis. Biol. Cell 47, 331-342.

Goldstein, L., Rubin, R., and Ko, C. (1977a). The presence of actin in nuclei: a critical appraisal. Cell 12, 601-608.

Goldstein, L., Ko, C., and Errick, J. (1977b). Nuclear actin: an apparent association with condensed chromatin. Cell Biol. Int. Rep. 1, 511-515.

Gounon, P., and Karsenti, E. (1981). Involvement of contractile proteins in the changes in consistency of oocyte nucleoplasm of the newt Pleurodeles waltlii. J. Cell Biol. 88, 410-421.

Graessmann, M., and Graessmann, A. (1976). "Early" simian-virus-40-specific RNA contains information for tumor antigen formation and chromatin replication. Proc. Nat. Acad. Sci. USA 73, 366-370.

Green, M. R., Maniatis, T., and Melton, D. A. (1983). Human $\beta$-globin premRNA synthesized in vitro is accurately spliced in Xenopus oocyte nuclei. Cell 32, 681-694.

Gurdon, J. B. (1976). Injected nuclei in frog oocytes: fate, enlargement, and chromatin dispersal. J. Embryol. Exp. Morph. 36, 523-540.

Gurdon, J. B., and Brown, D. D. (1978). The transcription of 5 S DNA injected into Xenopus oocytes. Dev. Biol. 67, 346-356.

Gurdon, J. B., and Melton, D. A. (1981). Gene transfer in amphibian eggs and oocytes. Ann. Rev. Genet. 15, 189-218.

Hasegawa, T., Takahashi, S., Hayashi, H., and Hatano, S. (1980). Fragmin: a calcium ion sensitive regulatory factor on the formation of actin filaments. Biochemistry 19, 2677-2683

Hauser, M., Hausmann, K., and Jockusch, B. M. (1980). Demonstration of tubulin, actin and alpha actinin by immunofluorescence in the microtubulemicrofilament complex of the cytopharyngeal basket of the ciliate Pseudomicrothorax dubius. Exp. Cell Res. 125, 265-274.

Hinssen, H. (1981a). An actin-modulating protein from Physarum polycephalum. I. Isolation and purification. Eur. J. Cell Biol. 23, 225-233.

Hinssen, H. (1981b). An actin-modulating protein from Physarum polycephalum. II. $\mathrm{Ca}^{++}$-dependence and other properties. Eur. J. Cell Biol. 23, 234240

Hinssen, H., Small, J. V., and Sobieszek, A. (1984). A Ca ${ }^{2+}$-dependent actin modulator from vertebrate smooth muscle. FEBS Lett. 166, 90-95.

Hoessli, D., Rungger-Brändle, E., Jockusch, B. M., and Gabbiani, G. (1980). Lymphocyte alpha actinin: relationship with cell membrane and co-capping with surface receptors. J. Cell Biol. 84, 305-314.

Izawa, M., Allfrey, V. G., and Mirsky, A. E. (1963). The relationship between RNA synthesis and loop structure in lampbrush chromosomes. Proc. Nat. Acad. Sci. USA 49, 544-551.

Jockusch, B. M., Becker, M., Hindennach, I., and Jockusch, H. (1974). Slime mould actin: homology to vertebrate actin and presence in the nucleus. Exp. Cell Res. 89, 241-246.

Jockusch, B. M., Burger, M. R., Da Prada, M., Richardson, J. G., Chaponnier, C., and Gabbiani, G. (1977). Alpha actinin attached to membranes of secretory vesicles. Nature 270, 628-629.

Jockusch, B. M., Kelley, K. H., Meyer, R. K., and Burger, M. M. (1978). An efficient method to produce anti-actin. Histochem. 55, 177-184.

Jockusch, B. M., Haemmerli, G., and In Albon, A. (1983). Cytoskeletal organisation in an epithelial cell with high locomotory activity (V2 rabbit carcinoma). Exp. Cell Res. 144, 251-263.

Jockusch, H., Jockusch, B. M., and Burger, M. M. (1979). Nerve fibers in 
culture and their interactions with non-neural cells visualized by immunofluorescence. J. Cell Biol. 80, 629-641.

Karsenti, E., Gounon, P., and Bornens, M. (1978). Immunocytochemical study of lampbrush chromosomes: presence of tubulin and actin. Biol. Cell $31,219-224$.

Kleinschmidt, J. A., Scheer, U., Dabauvalle, M.-C., Bustin, M., and Franke, W. W. (1983). High mobility group proteins of amphibian oocytes: a large storage pool of a soluble high mobility group-1-like protein and involvement in transcriptional events. J. Cell Biol. 97, 838-848.

Kleinschmidt, J. A., Fortkamp, E., Krohne, G., Zentgraf, H., and Franke, W. W. (1984). Co-existence of two different types of soluble histone complexes in nuclei of Xenopus laevis oocytes. J. Biol. Chem., in press.

Krohne, G., and Franke, W. W. (1980a). A major soluble acidic protein located in nuclei of diverse vertebrate species. Exp. Cell Res. 129, $167-$ 189.

Lacroix, J. C. (1968). Étude descriptive des chromosomes en ecouvillon dans le genre Pleurodeles (amphibien, urodele). Ann. Embryol. Morphogen. 1. 179-202

Lane, N. J. (1969). Intranuclear fibrillar bodies in actinomycin D-treated oocytes. J. Cell Biol. 40, 286-291.

Lazarides, E., and Lindberg, U. (1974). Actin is the naturally occurring inhibitor of deoxyribonuclease I. Proc. Nat. Acad. Sci. USA 71, 4742-4746. LeStourgeon, W. M. (1978). The occurrence of contractile proteins in nuclei and their possible functions. In The Cell Nucleus, 6, H. Busch, ed. (New York: Academic Press), pp. 305-326.

LeStourgeon, W. M., Forer, A., Yang, Y.-Z., Bertram, J. S., and Rusch, H. P. (1975). Contractile proteins. Major components of nuclear and chromosome non-histone proteins. Biochim. Biophys. Acta 379, 529-552.

MacGregor, H. C., and Callan, H. G. (1962). The actions of enzymes on lampbrush chromosomes. Quart. J. Microscop. Sci. 103, 173-203.

Mancino, G., Nardi, I., Corvaja, N., Fiume, L., and Marinozzi, V. (1971). Effects of $\alpha$-amanitin on Triturus lampbrush chromosomes. Exp. Cell Res. 64, 237-242.

Mertz, J. E., and Gurdon, J. B. (1977). Purified DNAs are transcribed after microinjection into Xenopus oocytes. Proc. Nat. Acad. Sci. USA 74, 15021506.

Miller, D. S., Lau, Y.-T., and Horowitz, S. B. (1984). Artifacts caused by cell microinjection. Proc. Nat. Acad. Sci. USA 81, 1426-1430.

Miller, O. L. (1981). The nucleolus, chromosomes, and visualization of genetic activity. J. Cell Biol. 91, 15s-27s.

Miller, O. L., and Beatty, B. R. (1969). Visualization of nucleolar genes. Science 164, 955-957.

Miller, O. L., and Bakken, A. H. (1972). Morphological studies of transcription. Acta Endocrinol. Suppl. 168, 155-177.

Morgan, G. T., Macgregor, H. C., and Colman, A. (1980). Multiple ribosomal gene sites revealed by in situ hybridization of Xenopus rDNA to Triturus lampbrush chromosomes. Chromosoma 80, 309-330.

Ohnishi, T., Kawamura, H., and Tanaka, Y. (1964). Die Aktin und Myosin ähnlichen Proteine im Kalbsthymuszellkern. J. Biochem. 56, 6-15.

Pardee, J. D., and Spudich, J. A. (1982). Purification of muscle actin. Meth. Cell Biol. 24, 271-289.

Paulin, D., Nicolas, J.-F., Jacquet, M., Jakob, H., Gros, F., and Jacob, F. (1976). Comparative protein patterns in chromatins from mouse teratocarcinoma cells. Exp. Cell Res. 102, 169-178

Pederson, T. (1977). Isolation and characterization of chromatin from the cellular slime mold, Dicytostelium discoideum. Biochemistry 16, 2771-2777. Peterson, J. L., and McConkey, E. H. (1976). Non-histone chromosomal proteins from HeLa cells. J. Biol. Chem. 251, 548-554.

Probst, E., Kressmann, A., and Birnstiel, M. L. (1979). Expression of sea urchin histone genes in the oocyte of Xenopus laevis. J. Mol. Biol. 135, 709-732.

Reddy, R., and Busch, H. (1983). Small nuclear RNAs and RNA processing Progr. Nucl. Acid Res. Mol. Biol. 30, 127-162.

Renkawitz, R., Beug, H., Graf, T., Matthias, P., Grez, M., and Schütz, G. (1982). Expression of a chicken lysozyme recombinant gene is regulated by progesterone and dexamethasone after microinjection into oviduct cells. Cell 31, 167-176

Rubin, R. W., Goldstein, L., and Ko, C. (1978). Differences between nucleus and cytoplasm in the degree of actin polymerization. J. Cell Biol. 77, 698701.

Rungger, D., Rungger-Brändle, E., Chaponnier, C., and Gabbiani, G. (1979) Intranuclear injection of anti-actin antibodies into Xenopus oocytes blocks chromosome condensation. Nature 282, 320-321.

Sanger, J. W., Sanger, J. M., Kreis, T. E., and Jockusch, B. M. (1980). Reversible translocation of cytoplasmic actin into the nucleus caused by dimethyl sulfoxide. Proc. Nat. Acad. Sci. USA 77, 5268-5272.

Scheer, U. (1978). Changes of nucleosome frequency in nucleolar and non-nucleolar chromatin as a function of transcription: an electron microscopic study. Cell 13, 535-549.

Scheer, U., and Zentgraf, H. (1982). Morphology of nucleolar chromatin in electron microscopic spread preparations. In The Cell Nucleus, 11, $\mathrm{H}$. Busch, and L. Rothblum, eds. (New York: Academic Press), pp. 143-176. Scheer, U., Trendelenburg, M. F., and Franke, W. W. (1976). Regulation of transcription of genes of ribosomal RNA during amphibian oogenesis. J. Cell Biol. 69, 465-489.

Scheer, U., Sommerville, J., and Bustin, M. (1979a). Injected histone antibodies interfere with transcription of lampbrush chromosome loops in oocytes of Pleurodeles. J. Cell Sci. 40, 1-20.

Scheer, U., Spring, H., and Trendelenburg, M. F. (1979b). Organization of transcriptionally active chromatin in lampbrush chromosome loops. In The Cell Nucleus, 7, H. Busch, ed. (New York: Academic Press), pp. 3-47.

Schröder, H. C., Zahn, R. K., and Müller, W. E. G. (1982). Role of actin and tubulin in the regulation of poly(A)polymerase-endoribonuclease IV complex from calf thymus. J. Biol. Chem. 257, 2305-2309.

Schultz, L. D., Kay, B. K., and Gall, J. G. (1981). In vitro RNA synthesis in oocyte nuclei of the newt Notophthalmus. Chromosoma (Berl.) 82, 171187.

Sixma, J. J., Schiphorst, M. E., Verhoeckx, C., and Jockusch, B. M. (1982). Extrinsic and intrinsic proteins of blood platelet membranes: alpha actinin is not identical with glycoprotein III. Biochim. Biophys. Acta 704, 333-344.

Smith, S. S., Kelly, K. H., and Jockusch, B. M. (1979). Actin co-purifies with RNA polymerase II. Biochem. Biophys. Res. Commun. 86, 161-166.

Snow, M. H. L., and Callan, H. G. (1969). Evidence for a polarized movement of the lateral loops of newt lampbrush chromosomes during oogenesis. J. Cell Sci. 5, 1-25.

Sollner-Webb, B., and McKnight, S. L. (1982). Accurate transcription of cloned Xenopus rRNA genes by RNA polymerase I: demonstration by S1 nuclease mapping. Nucl. Acids Res. 10, 3391-3405.

Sommerville, J. (1977). Gene activity in the lampbrush chromosomes of amphibian oocytes. Int. Rev. Biochem. 15, 79-156.

Spring, H., and Franke, W. W. (1981). Transcriptionally active chromatin in loops of lampbrush chromosomes at physiological salt concentrations as revealed by electron microscopy of sections. Eur. J. Cell Biol. 24, 298-308. Trendelenburg, M. F., Zentgraf, H., Franke, W. W., and Gurdon, J. B. (1978). Transcription patterns of amplified Dytiscus genes coding for ribosomal RNA after injection into Xenopus oocyte nuclei. Proc. Nat. Acad. Sci. USA 75, 3791-3795.

Vandekerckhove, J., Franke, W. W., and Weber, K. (1981). Diversity of expression of non-muscle actin in amphibia. J. Mol. Biol. 152, 413-426.

Wehland, J., Weber, K., and Osborn, M. (1980). Translocation of actin from the cytoplasm into the nucleus in mammalian cells exposed to dimethylsulfoxide. Biol. Cell 39, 109-111.

Wieland, T., and Faulstich, H. (1978). Amatoxins, phallotoxins, phallolysin and antamanide: the biologically active components of poisonous Amanita mushrooms. Crit. Rev. Biochem. 5, 185-260. 